\title{
Methanosarcina horonobensis sp. nov., a methanogenic archaeon isolated from a deep subsurface Miocene formation
}

Correspondence

Satoru Shimizu satoru.shimizu@h-rise.jp

\author{
Satoru Shimizu, ${ }^{1}$ Rahul Upadhye, ${ }^{1}$ Yoji Ishijima ${ }^{1}$ and Takeshi Naganuma ${ }^{2}$ \\ ${ }^{1}$ Horonobe Research Institute for the Subsurface Environment, Northern Advancement Center for \\ Science and Technology, Horonobe-cho, Teshio-gun, Hokkaido 098-3221, Japan \\ ${ }^{2}$ Graduate School of Biosphere Science, Hiroshima University, Higashi-Hiroshima 739-8528, \\ Japan
}

\begin{abstract}
A methanogenic organism, designated strain $\mathrm{HB}-1^{\top}$, from the domain Archaea was isolated from groundwater sampled from a subsurface Miocene formation located in Horonobe, Hokkaido, Japan. The strain grew on methanol, dimethylamine, trimethylamine, dimethylsulfide and acetate but not on monomethylamine, $\mathrm{H}_{2} / \mathrm{CO}_{2}$, formate, 2-propanol, 2-butanol or cyclopentanol. Cells were Gram-reaction-negative, non-motile, irregular cocci that were 1.4-2.9 $\mu \mathrm{m}$ in diameter and occurred singly or in pairs. The strain grew at $20-42^{\circ} \mathrm{C}$ (optimum $37{ }^{\circ} \mathrm{C}$ ), at pH $6.0-7.75$ (optimum pH 7.0-7.25) and in $0-0.35 \mathrm{M} \mathrm{NaCl}$ (optimum $0.1 \mathrm{M}$ ). The $\mathrm{G}+\mathrm{C}$ content of the genomic DNA was 41.4 mol\%. 16S rRNA gene sequencing revealed that the strain was a member of the genus Methanosarcina but that it clearly differed from all recognized species of this genus (93.1-97.9\% sequence similarity). The phenotypic and phylogenetic features of strain $\mathrm{HB}-1^{\top}$ indicate that it represents a novel species of the genus Methanosarcina, for which the name Methanosarcina horonobensis sp. nov. is proposed. The type strain is $\mathrm{HB}-1^{\top}$ (=DSM $21571^{\top}=$ JCM $15518^{\top}=$ NBRC $102577^{\top}$ ).
\end{abstract}

To date, few methanogens have been isolated from deep terrestrial subsurface environments other than oilfields (Christian et al., 2005); these include Methanobacterium subterraneum, isolated from deep granitic groundwater (Kotelnikova et al., 1998); Methanolobus zinderi, from a deep coal seam (Doerfert et al., 2009); and Methanolobus profundi, from a gas field (Mochimaru et al., 2009).

The Wakkanai Formation is a Miocene structure in northernmost Japan. It consists of layers of siliceous mudstone (Fukusawa, 1987). Palaeo-seawater and methane are trapped in the formation (Iwatsuki et al., 2009). Previously, we used 16S rRNA gene sequences to characterize the community structure of resident methanogens by extracting DNA from water taken from 288.7-644.1 m below ground level from the Horonobe area of the formation. Our results indicated that the archaeal 16S rRNA gene libraries were dominated by methanogen clones that were mostly related to members of the genera Methanoculleus and Methanosarcina (Shimizu et al., 2006). However, to our knowledge, no methane-producing strains

The GenBank/EMBL/DDBJ accession number for the $16 \mathrm{~S}$ rRNA gene sequence of strain $\mathrm{HB}-1^{\top}$ is $\mathrm{AB} 288262$.

Three supplementary figures are available with the online version of this paper. have yet been isolated from the formation for further characterization.

In this study, we describe the characteristics of a methanogenic archaeon, designated strain $\mathrm{HB}-1^{\mathrm{T}}$, which was sampled from an aquifer at the Wakkanai Formation.

A groundwater sample was collected on 15th January 2005 from the Wakkanai Formation by using previously described methods (Shimizu et al., 2006). The sample was extracted 288.7-303.0 m below ground level from survey borehole HDB-6, which was drilled by the Japan Atomic Energy Agency (JAEA) in the Horonobe area.

Groundwater samples were inoculated into modified DSM 120 medium (http://www.dsmz.de/microorganisms/medium/ pdf/DSMZ_Medium120.pdf), in which the concentrations of L-cysteine- $\mathrm{HCl} . \mathrm{H}_{2} \mathrm{O}$ and $\mathrm{Na}_{2} \mathrm{~S} .9 \mathrm{H}_{2} \mathrm{O}$ were changed to $0.5 \mathrm{~g} \mathrm{l}^{-1}$, and incubated at $37{ }^{\circ} \mathrm{C}$ in an $\mathrm{N}_{2} / \mathrm{H}_{2} / \mathrm{CO}_{2}$ $(80: 10: 10, \mathrm{v} / \mathrm{v} / \mathrm{v})$ atmosphere. The enrichment culture, which actively produced methane, was periodically transferred to fresh medium. After 14 days of incubation on solid medium, shiny, convex, clear and yellowish colonies were formed. Colonies were circular, with diameters of $0.5-1.0 \mathrm{~mm}$ and had entire margins.

An epifluorescence microscope (BX-51; Olympus) was used to perform phase-contrast and autofluorescence 
microscopy of cells in the exponential phase. The resulting images revealed that cells were irregular cocci, 1.4-2.9 $\mu \mathrm{m}$ in diameter and occurred singly or in pairs (Supplementary Fig. S1a, b, available in IJSEM Online). No motility was observed under phase-contrast microscopy and no flagella were seen when negatively stained cells were observed using transmission electron microscopy (JEM-2000EX; JEOL) (Supplementary Fig. S1c). Cells of strain $\mathrm{HB}-1^{\mathrm{T}}$ were found to be Gram-reaction negative and lysed in a $0.01 \%(\mathrm{w} / \mathrm{v})$ SDS solution.

To determine growth conditions and substrate utilization patterns, samples were cultured using DSM 120 medium modified as before, but with the concentration of $\mathrm{NaCl}$ changed to $0.1 \mathrm{M}$. The headspace was filled with $\mathrm{H}_{2} / \mathrm{CO}_{2}$ $(80: 20, \mathrm{v} / \mathrm{v} ; 200 \mathrm{kPa})$ to examine the utilization of $\mathrm{H}_{2} / \mathrm{CO}_{2}$ as a methanogenic substrate or $\mathrm{N}_{2} / \mathrm{CO}_{2}(80: 20, \mathrm{v} / \mathrm{v})$ to study the utilization of other substrates. The $\mathrm{pH}$ of the medium was adjusted by adding $\mathrm{HCl}$ or $\mathrm{NaOH}$ solution. Cultures were incubated in triplicate under each set of conditions. A UVmini-1240 spectrophotometer (Shimadzu) was used to measure $\mathrm{OD}_{660}$ in order to ascertain growth rates. Strain $\mathrm{HB}-1^{\mathrm{T}}$ grew at $20-42{ }^{\circ} \mathrm{C}$ and $\mathrm{pH} 7.0$ with an optimum growth temperature of $37{ }^{\circ} \mathrm{C}$ (Supplementary Fig. S2a). No growth occurred within 2 months at $15{ }^{\circ} \mathrm{C}$ or $45{ }^{\circ} \mathrm{C}$. The optimum $\mathrm{pH}$ for growth was 7.0-7.25 (the initial $\mathrm{pH}$ of the culture medium), although growth was observed at $\mathrm{pH}$ 6.0-7.75; no growth was observed within 2 months at pH 5.5 or 8.0 (Supplementary Fig. S2b). Strain $\mathrm{HB}-1^{\mathrm{T}}$ grew in the presence of $0-0.35 \mathrm{M} \mathrm{NaCl}$, with an optimum concentration of $0.1 \mathrm{M}$ (Supplementary Fig. S2c). Furthermore, growth was observed in the presence of 0 $0.75 \mathrm{M} \mathrm{MgSO}_{4}$, with an optimum concentration of $0-0.2 \mathrm{M}$ (Supplementary Fig. S2d). No growth occurred within 2 months in medium supplemented with $0.4 \mathrm{M} \mathrm{NaCl}$ or $0.8 \mathrm{M} \mathrm{MgSO}_{4}$.

Strain $\mathrm{HB}-1^{\mathrm{T}}$ used (20 mM each) methanol, dimethylamine, trimethylamine, dimethylsulfide and acetate as methanogenic substrates. The strain exhibited good growth $\left(0.14,0.09\right.$ and $0.07 \mathrm{~h}^{-1}$, respectively) on methanol, trimethylamine and dimethylamine but very slow growth on dimethylsulfide and acetate. Growth and methane formation were not observed on $\mathrm{H}_{2} / \mathrm{CO}_{2}(80: 20$, v/v; 200 $\mathrm{kPa})$ or on (20 mM each) monomethylamine, formate, 2propanol, 2-butanol or cyclopentanol. Growth of the strain was stimulated by Bacto yeast extract and Bacto casitone (BD). Furthermore, vitamins and trace minerals were required for growth in the DSM 120 medium.

The sensitivity of strain $\mathrm{HB}-1^{\mathrm{T}}$ to $\left(100 \mu \mathrm{g} \mathrm{l^{-1 }}\right.$ each) antibiotics such as ampicillin, penicillin $\mathrm{G}$, vancomycin, kanamycin and tetracycline was tested at $37{ }^{\circ} \mathrm{C}$ and $\mathrm{pH}$ 7.0. Strain $\mathrm{HB}-\mathrm{I}^{\mathrm{T}}$ was resistant to all antibiotics except tetracycline, with which no growth occurred within 2 months.

Cells of strain HB- $1^{\mathrm{T}}$ were harvested in late exponential phase and used for DNA isolation according to previously described methods (Marmur, 1961). Crude DNA was purified according to the method of Hamamoto \& Nakase (1995). HPLC with an LC-10A component (Shimadzu) was used to determine the $\mathrm{G}+\mathrm{C}$ content of the DNA (Katayama-Fujimura et al., 1984); this was found to be $41.4 \pm 0.4$ mol\% (mean $\pm \mathrm{SD}, n=3$ ).

The 16S rRNA gene of strain $\mathrm{HB}-1^{\mathrm{T}}$ was amplified using the primers A25F (5'-CYGGTTGATCCTGCCRG-3', where $\mathrm{Y}=\mathrm{C}$ or $\mathrm{T}$ and $\mathrm{R}=\mathrm{A}$ or $\mathrm{G})$ and U1492R ( $5^{\prime}$-GGTTACCTTGTTACGACTT-3'), according to Dojka et al. (1998). The amplified PCR product was sequenced as previously described (Shimizu et al., 2006), using the following sequencing primers: A25F (as above), U533F (5'-GTGCCAGCMGCCGCGGTAA-3', where $\mathrm{M}=\mathrm{A}$ or $\mathrm{C}$; Dojka et al., 1998), 0922F (5'-GAAACTTAAAKGAATTG-3', where $\mathrm{K}=\mathrm{G}$ or T; Achenbach \& Woese, 1995), 1100F (5'GGCAACGAGCGMGACCC-3'; Lane, 1991), U1492R (as above), 1098Ra (5'-GGGTCTCGCTCGTTSCC-3', where $\mathrm{S}=\mathrm{C}$ or G; Mikucki et al., 2003), U907R (5'-CCGTCAATTCCTTTRAGTTT-3'; Dojka et al., 1998), 536-519r (5'GWATTACCGCGGCKGCTG-3', where $\mathrm{W}=\mathrm{A}$ or $\mathrm{T}$; Lane et al., 1985), 368-353r (5'-AGKTTTCGCGCCTGCT-3'; Kotelnikova et al., 1998) and 0112aR (5'-CCACGTGTTACTSAGC-3'; Achenbach \& Woese, 1995).

The BLAST search tool was used to compare the nearly complete (1432 bp) 16S rRNA gene sequence of strain $\mathrm{HB}^{\mathrm{T}}{ }^{\mathrm{T}}$ to sequences in the DNA database. Searches revealed that strain $\mathrm{HB}-1^{\mathrm{T}}$ was most closely related to strains belonging to the genus Methanosarcina (93.1-97.9\% 16S rRNA gene sequence similarity) with highest similarity values between strain $\mathrm{HB}-1^{\mathrm{T}}$ and $M$. barkeri $\mathrm{MS}^{\mathrm{T}}(97.9 \%)$ and M. mazei S- $6^{\mathrm{T}}(97.2 \%)$, followed by $M$. acetivorans

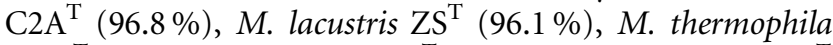
$\mathrm{TM}^{\mathrm{T}}$ (96.0\%), M. frisia $\mathrm{C} 6^{\mathrm{T}}$ (95.8\%), M. siciliae $\mathrm{T} 4 / \mathrm{M}^{\mathrm{T}}$ (94.7\%), M. semesiae $\mathrm{MD1}^{\mathrm{T}}$ (94.7\%), M. baltica GS1-A ${ }^{\mathrm{T}}$ $(94.0 \%)$ and M. vacuolata Z-761 ${ }^{\mathrm{T}}(93.1 \%)$. Interestingly, the $16 \mathrm{~S}$ rRNA gene sequence of strain $\mathrm{HB}-1^{\mathrm{T}}$ was most similar $(99.9 \%)$ to that of uncultured clone HDBWWA05 (accession no. AB237738), which had previously been obtained from deep subsurface groundwater of the Wakkanai Formation in the Horonobe area (Shimizu et al., 2006).

Phylogenetic trees reconstructed using the neighbour-joining, maximum-parsimony and minimum evolution methods showed that strain $\mathrm{HB}_{-1}{ }^{\mathrm{T}}$ clustered with members of the genus Methanosarcina and was most closely related to M. mazei S- $6^{\mathrm{T}}$ and M. frisia $\mathrm{C} 16^{\mathrm{T}}$ (Fig. 1 and Supplementary Fig. S3). M. frisia has been proposed as a synonym of $M$. mazei since DNA-DNA hybridization values between the type strains were $77 \%$ similar and because the two species have a similar physiology (Maestrojuán et al., 1992). Bootstrap analysis indicated a clear branching of strain $\mathrm{HB}-1^{\mathrm{T}}$ from these species.

Strain $\mathrm{HB}-\mathrm{1}^{\mathrm{T}}$ had different phenotypic properties and substrate utilization characteristics to those of its closest phylogenetic relative, M. mazei and other related type strains (Table 1), as well as a lower tolerance of $\mathrm{NaCl}$. 


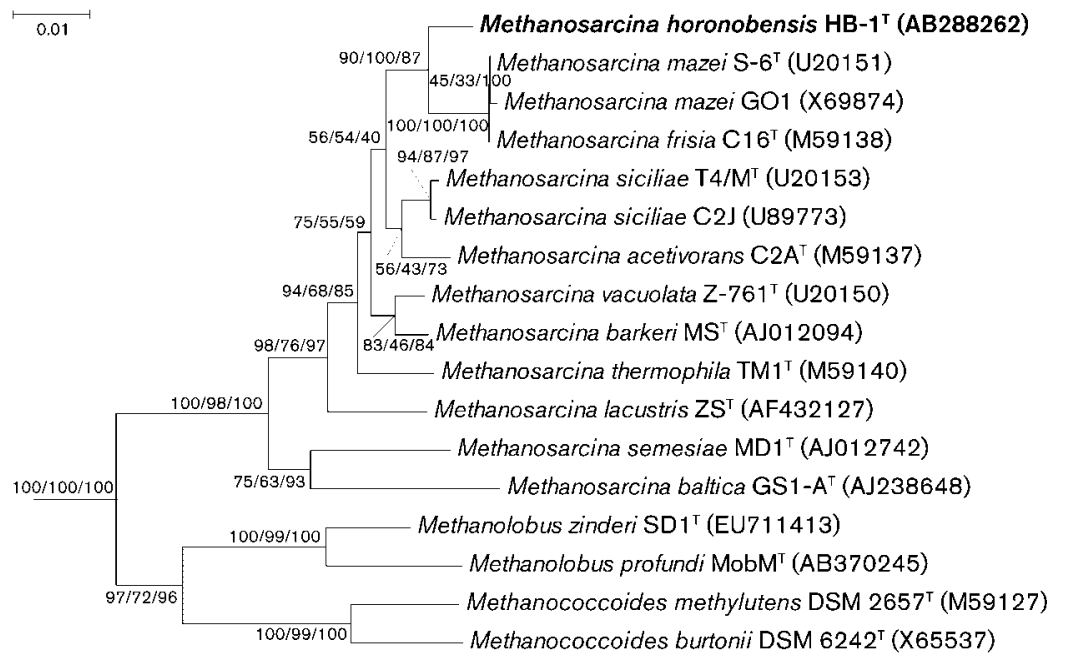

Fig. 1. Phylogenetic tree based on 16S rRNA gene sequences showing the relationship between strain $\mathrm{HB}-1^{\top}$ and members of the genera Methanosarcina and related taxa. The tree was reconstructed using the neighbourjoining method. The two 16S rRNA gene sequences of Methanospirillum hungatei JF$1 \mathrm{D}^{\top}$ (M60880) and Methanococcus maripaludis DSM2067 ${ }^{\top}$ (AF005049) were used to root the tree (not shown). Tree topology was evaluated by bootstrap analysis (based on 1000 replicates) with the neighbour-joining/ maximum-parsimony/minimum evolution methods, using the MEGA 4.0 program package (Kumar et al., 2008). Bar, 0.01 substitutions per nucleotide position.

Unlike $M$. mazei, strain $\mathrm{HB}-1^{\mathrm{T}}$ was unable to use monomethylamine or $\mathrm{H}_{2} / \mathrm{CO}_{2}$; the other related type strains could also use monomethylamine. In addition to this, strain $\mathrm{HB}-1^{\mathrm{T}}$ was tolerant of a much lower concentration of $\mathrm{NaCl}(0.35 \mathrm{M})$ than $M$. mazei $(1.0 \mathrm{M})$ and other related type strains $(\geqslant 0.6 \mathrm{M})$.

A SpectraFluor Plus (model F0129005; GENios) fluorescence, absorbance and luminescence instrument was used to quantify DNA-DNA hybridization values according to the method described by Ezaki et al. (1989). Strain HB-1 ${ }^{\mathrm{T}}$ and its closest relative, M. mazei S- $6^{\mathrm{T}}$, showed a relatedness value of $14 \%$. Even lower relatedness values were observed between strain $\mathrm{HB}-1^{\mathrm{T}}$ and $M$. barkeri $\mathrm{MS}^{\mathrm{T}}(13 \%), M$. acetivorans $\mathrm{C} 2 \mathrm{~A}^{\mathrm{T}}$ (9\%), M. vacuolata $\mathrm{Z}-761^{\mathrm{T}}(6 \%)$ and $M$. siciliae $\mathrm{T} 4 / \mathrm{M}^{\mathrm{T}}(3 \%)$. Genomic relatedness between strain $\mathrm{HB}-1^{\mathrm{T}}$ and these type strains was too low to identify strain $\mathrm{HB}-1^{\mathrm{T}}$ as belonging to any existing species of the genus Methanosarcina.

Therefore, on the basis of the phenotypic and phylogenetic data, strain $\mathrm{HB}-\mathrm{1}^{\mathrm{T}}$ represents a novel species of the genus

Table 1. Characteristics of strain $\mathrm{HB}-1^{\top}$ and species of the genus Methanosarcina

Strains: $1, \mathrm{HB}-1^{\mathrm{T}}$ (data from this study); 2, M. mazei S-6 ${ }^{\mathrm{T}}$ (Mah \& Kuhn, 1984; Maestrojuán \& Boone, 1991); 3, M. frisia C16 ${ }^{\mathrm{T}}$ (Blotevogel et al.,

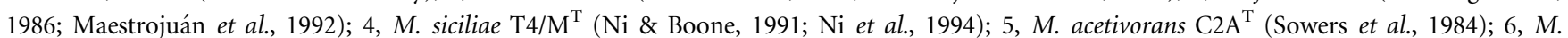
vacuolata Z-761 ${ }^{\mathrm{T}}$ (Zhilina \& Zavarzin, 1987; Maestrojuán \& Boone, 1991); 7. M. barkeri MS ${ }^{\mathrm{T}}$ (Bryant \& Boone, 1987; Maestrojuán \& Boone, 1991); 8, M. thermophila TM1 ${ }^{\mathrm{T}}$ (Zinder et al., 1985; Zinder \& Mah, 1979); 9, M. lacustris ZS ${ }^{\mathrm{T}}$ (Simankova et al., 2001); 10, M. semesiae MD1 ${ }^{\mathrm{T}}$ (Lyimo et al., 2000); 11, M. baltica GS1-A ${ }^{\mathrm{T}}$ (von Klein et al., 2002). All strains were positive for utilization of methanol and trimethylamine. + , Positive; - , negative; ND, not determined.

\begin{tabular}{|c|c|c|c|c|c|c|c|c|c|c|c|}
\hline Cell size $(\mu \mathrm{m})$ & $1.4-2.9$ & $1.0-3.0$ & $0.9-1.6$ & $1.5-3.0$ & 1.9 & $1.0-2.0$ & $1.5-2.0$ & $\mathrm{ND}$ & $1.5-3.5$ & $1.4 \pm 0.2$ & $1.5-3.0$ \\
\hline Gram stain & - & - & - & - & - & + & + & + & + & + & ND \\
\hline Optimum temperature $\left({ }^{\circ} \mathrm{C}\right)$ & 37 & $40-42$ & 36 & 40 & $35-40$ & $37-40$ & $40-42$ & 50 & 25 & $30-35$ & 25 \\
\hline $\mathrm{pH}$ range for growth & $6.0-7.75$ & $5.5-8.5$ & $6.5-7.2$ & $6.0-7.7$ & $5.5-8.0$ & $5.0-7.0$ & $5.0-8.0$ & $5.5-8.0$ & $4.5-8.5$ & $6.2-8.3$ & $4.0-8.5$ \\
\hline Tolerance of $\mathrm{NaCl}(\mathrm{M})$ & $0-0.35$ & $0.1-1.0$ & $0.1-1.0$ & $0->1.7$ & $0.1-1.0$ & $0.1-0.6$ & $0.1-0.8$ & $\mathrm{ND}$ & $\mathrm{ND}$ & $0-1.0$ & $0.2-1.2$ \\
\hline $\begin{array}{l}\text { Optimum } \mathrm{NaCl} \text { for } \\
\text { growth }(\mathrm{M})\end{array}$ & 0.1 & $0.1-0.3$ & $0.1-0.2$ & $0.4-0.6$ & $0.1-0.6$ & $0.1-0.2$ & 0.1 & $\mathrm{ND}$ & $\mathrm{ND}$ & $0.2-0.6$ & $0.3-0.4$ \\
\hline \multicolumn{12}{|l|}{ Utilization of: } \\
\hline $\mathrm{H}_{2} / \mathrm{CO}_{2}$ & - & + & + & - & - & + & + & + & + & - & - \\
\hline Monomethylamine & - & + & + & $\mathrm{ND}$ & + & + & + & + & + & + & + \\
\hline
\end{tabular}


Methanosarcina, for which the name Methanosarcina horonobensis sp. nov. is proposed.

\section{Description of Methanosarcina horonobensis sp. nov.}

Methanosarcina horonobensis (ho.ro.no.ben'sis. N.L. fem. adj. horonobensis belonging to Horonobe, the town in Hokkaido, Japan, from which the strain was isolated).

Cells are strictly anaerobic, gram-reaction-negative, irregular cocci that are $1.4-2.9 \mu \mathrm{m}$ in diameter and lysed by $0.01 \%$ (w/v) SDS. Grows on methanol, dimethylamine, trimethylamine, dimethylsulfide and acetate but not on monomethylamine, $\mathrm{H}_{2} / \mathrm{CO}_{2}$, formate, 2-propanol, 2-butanol or cyclopentanol. Cells grow at $20-42{ }^{\circ} \mathrm{C}$ (optimum $37{ }^{\circ} \mathrm{C}$ ), at pH 6.0-7.75 (optimum pH 7.0-7.25), in $0-0.35 \mathrm{M} \mathrm{NaCl}$ (optimum $0.1 \mathrm{M}$ ) and with $0-0.7 \mathrm{M} \mathrm{MgSO}_{4}$ (optimum $0-0.2 \mathrm{M})$.

The type strain, HB-1 ${ }^{\mathrm{T}}\left(=\mathrm{DSM} 21571^{\mathrm{T}}=\mathrm{JCM} 15518^{\mathrm{T}}\right.$ $=$ NBRC $102577^{\mathrm{T}}$ ), was isolated in Horonobe, Japan, from deep subsurface groundwater from a siliceous mudstone formation. The DNA $\mathrm{G}+\mathrm{C}$ content of the type strain is $41.4 \pm 0.4 \mathrm{~mol} \%$.

\section{Acknowledgements}

This work was supported by the Ministry of Economy, Trade and Industry (METI) of Japan. Deep subsurface groundwater was provided by Japan Atomic Energy Agency (JAEA).

\section{References}

Achenbach, L. \& Woese, C. (1995). $16 \mathrm{~S}$ and $23 \mathrm{~S}$ rRNA-like primers. In Archaea: A Laboratory Manual: Methanogens, pp. 521-523. Edited by K. R. Sowers \& H. J. Schreier. Cold Spring Harbor, NY: Cold Spring Harbor Laboratory.

Blotevogel, K. H., Fischer, U. \& Lüpkes, K. H. (1986). Methanococcus frisius sp. nov., a new methylotrophic marine methanogen. Can J Microbiol 32, 127-131.

Bryant, M. P. \& Boone, D. R. (1987). Emended description of strain $\mathrm{MS}^{\mathrm{T}}\left(\mathrm{DSM} 800^{\mathrm{T}}\right)$, the type strain of Methanosarcina barkeri. Int J Syst Bacteriol 37, 169-170.

Christian, J., Olivier, N., Erwan, C. \& Agnes, G. L. (2005). Hyperthermophilic and methanogenic archaea in oil fields. In Petroleum Microbiology, pp. 55-69. Edited by B. Ollivier \& M. Magot. Washington: American Society for Microbiology.

Doerfert, S. N., Reichlen, M., lyer, P., Wang, M. \& Ferry, J. G. (2009). Methanolobus zinderi sp. nov., a methylotrophic methanogen isolated from a deep subsurface coal seam. Int J Syst Evol Microbiol 59, 10641069.

Dojka, M. A., Hugenholtz, P., Haack, S. K. \& Pace, N. R. (1998). Microbial diversity in a hydrocarbon- and chlorinated-solventcontaminated aquifer undergoing intrinsic bioremediation. Appl Environ Microbiol 64, 3869-3877.

Ezaki, T., Hashimoto, Y. \& Yabuuchi, E. (1989). Fluorometric deoxyribonucleic acid-deoxyribonucleic acid hybridization in microdilution wells as an alternative to membrane filter hybridization in which radioisotopes are used to determine genetic relatedness among bacterial strains. Int J Syst Bacteriol 39, 224-229.
Fukusawa, H. (1987). [The site of sedimentation of Late Neogene bedded siliceous rock in northern Hokkaido, Japan]. J Geol Soc Japan 93, 37-55 (in Japanese with English abstract).

Hamamoto, M. \& Nakase, T. (1995). Ballistosporous yeasts found on the surface of plant materials collected in New Zealand. Antonie van Leeuwenhoek 67, 151-171.

Iwatsuki, T., Ishii, E. \& Niizato, T. (2009). Scenario development of long-term evolution for deep hydrochemical conditions in Horonobe area, Hokkaido, Japan. J Geog 118, 700-716.

Katayama-Fujimura, Y., Komatsu, Y., Kuraishi, H. \& Kaneko, T. (1984). Estimation of DNA base composition by high performance liquid chromatography of its nuclease P1 hydrolysate. Agric Biol Chem 48, 3169-3172.

Kotelnikova, S., Macario, A. J. L. \& Pedersen, K. (1998). Methanobacterium subterraneum sp. nov., a new alkaliphilic, eurythermic and halotolerant methanogen isolated from deep granitic groundwater. Int J Syst Bacteriol 48, 357-367.

Kumar, S., Nei, M., Dudley, J. \& Tamura, K. (2008). MEGA: a biologistcentric software for evolutionary analysis of DNA and protein sequences. Brief Bioinform 9, 299-306.

Lane, D. J. (1991). 16S/23S rRNA sequencing. In Nucleic Acid Techniques in Bacterial Systematics, pp. 115-175. Edited by E. Stackebrandt \& M. Goodfellow. New York: Wiley.

Lane, D. J., Pace, B., Olsen, G. J., Stahl, D. A., Sogin, M. L. \& Pace, N. R. (1985). Rapid determination of $16 \mathrm{~S}$ ribosomal RNA sequences for phylogenetic analyses. Proc Natl Acad Sci USA 82, 6955-6959.

Lyimo, T. J., Pol, A., Op den Camp, H. J. M., Harhangi, H. R. \& Vogels, G. D. (2000). Methanosarcina semesiae sp. nov., a dimethylsulfideutilizing methanogen from mangrove sediment. Int J Syst Evol Microbiol 50, 171-178.

Maestrojuán, G. M. \& Boone, D. R. (1991). Characterization of Methanosarcina barkeri $\mathrm{MS}^{\mathrm{T}}$ and 227 , Methanosarcina mazei $\mathrm{S}-6^{\mathrm{T}}$, and Methanosarcina vacuolata Z-761 ${ }^{\mathrm{T}}$. Int J Syst Bacteriol 41, 267-274.

Maestrojuán, G. M., Boone, J. E., Mah, R. A., Menaia, J. A. G. F., Sachs, M. S. \& Boone, D. R. (1992). Taxonomy and halotolerance of mesophilic Methanosarcina strains, assignment of strains to species, and synonymy of Methanosarcina mazei and Methanosarcina frisia. Int J Syst Bacteriol 42, 561-567.

Mah, R. A. \& Kuhn, D. A. (1984). Transfer of the type species of the genus Methanococcus to the genus Methanosarcina, naming it Methanosarcina mazei (Barker 1936) comb. nov. et emend. and conservation of the genus Methanococcus (Approved List 1980) with Methanococcus vannielii (Approved List 1980) as the type species. Int J Syst Bacteriol 34, 263-265.

Marmur, J. (1961). A procedure for the isolation of deoxyribonucleic acid from microorganisms. J Mol Biol 3, 208-218.

Mikucki, J. A., Liu, Y., Delwiche, M., Colwell, F. S. \& Boone, D. R. (2003). Isolation of a methanogen from deep marine sediments that contain methane hydrates, and description of Methanoculleus submarinus sp. nov. Appl Environ Microbiol 69, 3311-3316.

Mochimaru, H., Tamaki, H., Hanada, S., Imachi, H., Nakamura, K., Sakata, S. \& Kamagata, Y. (2009). Methanolobus profundi sp. nov., a methylotrophic methanogen isolated from deep subsurface sediments in a natural gas field. Int J Syst Evol Microbiol 59, 714-718.

Ni, S. S. \& Boone, D. R. (1991). Isolation and characterization of a dimethyl sulfide-degrading methanogen, Methanolobus siciliae HI350, from an oil well, characterization of $M$. siciliae $\mathrm{T} 4 / \mathrm{M}^{\mathrm{T}}$, and emendation of M. siciliae. Int J Syst Bacteriol 41, 410-416.

Ni, S., Woese, C. R., Aldrich, H. C. \& Boone, D. R. (1994). Transfer of Methanolobus siciliae to the genus Methanosarcina, naming it Methanosarcina siciliae, and emendation of the genus Methanosarcina. Int J Syst Bacteriol 44, 357-359. 
Shimizu, S., Akiyama, M., Ishijima, Y., Hama, K., Kunimaru, T. \& Naganuma, T. (2006). Molecular characterization of microbial communities in fault-bordered aquifers in the Miocene formation of northernmost Japan. Geobiology 4, 203-213.

Simankova, M. V., Parshina, S. N., Tourova, T. P., Kolganova, T. V., Zehnder, A. J. B. \& Nozhevnikova, A. N. (2001). Methanosarcina lacustris sp. nov., a new psychrotolerant methanogenic archaeon from anoxic lake sediments. Syst Appl Microbiol 24, 362-367.

Sowers, K. R., Baron, S. F. \& Ferry, J. G. (1984). Methanosarcina acetivorans sp. nov., an acetotrophic methane-producing bacterium isolated from marine sediments. Appl Environ Microbiol 47, 971-978. von Klein, D., Arab, H., Völker, H. \& Thomm, M. (2002). Methanosarcina baltica, sp. nov., a novel methanogen isolated from the Gotland Deep of the Baltic Sea. Extremophiles 6, 103-110.

Zhilina, T. N. \& Zavarzin, G. A. (1987). Methanosarcina vacuolata sp. nov., a vacuolated methanosarcina. Int J Syst Bacteriol 37, 281-283.

Zinder, S. H. \& Mah, R. A. (1979). Isolation and characterization of a thermophilic strain of Methanosarcina unable to use $\mathrm{H}_{2}-\mathrm{CO}_{2}$ for methanogenesis. Appl Environ Microbiol 38, 996-1008.

Zinder, S. H., Sowers, K. R. \& Ferry, J. G. (1985). Methanosarcina thermophila sp. nov., a thermophilic, acetotrophic, methaneproducing bacterium. Int J Syst Bacteriol 35, 522-523. 